УДК $634.2: 631.52: 631.535$

DOI 10.30679/2219-5335-2020-4-64-128-142

ВЫДЕЛЕНИЕ НОВЫХ

УСТОЙЧИВЫХ ПОДВОЕВ

ДЛЯ КРУПНОКОСТОЧКОВЫХ

КУЛЬТУР В УСЛОВИЯХ

ЮГА РОССИИ

Кузнецова Анна Павловна

канд. биол. наук

зав. лабораторией

питомниководства

e-mail: anpalkuz@mail.ru

Дрыгина Анна Игоревна

аспирант

младший научный сотрудник

лаб. питомниководства

e-mail: annisilent@mail.ru

Федоренко Александр Михайлович соискатель учёной степени

Федеральное государственное

бюджетное научное учреждение

«Северо-Кавказский федеральный

научный иентр садоводства,

виноградарства, виноделия»,

Краснодар, Россия

Маслова Марина Витальевна

канд. с.-х. наук

старший научный сотрудник

лаборатории биофотоники

e-mail: marinamaslova2009@mail.ru

Федеральное государственное

образовательное учреждение

высшего образования

«Мичуринский государственный

аграрный университет»,

Мичуринск, Россия

Для повышения продуктивности

и стабильности плодоношения растений

отрасль плодоводства нуждается

в использовании адаптивных сортов

и подвоев в конкретных зонах выращивания.

С учётом глобальных и локальных погодно-

климатических изменений выделение

генотипов, проявляющих устойчивость
UDC $634.2: 631.52: 631.535$

DOI 10.30679/2219-5335-2020-4-64-128-142

\section{SELECTION OF NEW RESISTANT ROOTSTOCKS FOR LARGE-STONE FRUIT CROPS UNDER THE CONDITIONS OF THE SOUTH OF RUSSIA}

Kuznetsova Anna Pavlovna

Cand. Biol. Sci.

Head of Nursery Plantation

Laboratory

e-mail: anpalkuz@mail.ru

Drygina Anna Igorevna

Postgraduate Student

Junior Research Associate

of Nursery Plantation Laboratory

e-mail: annisilent@mail.ru

Fedorenko Alexandr Mikhailovich

Academic Degree Applicant

Federal State Budget

Scientific Institution

"North Caucasian Federal

Scientific Center of Horticulture,

Viticulture, Wine-making»,

Krasnodar, Russia

Maslova Marina Vitalievna

Cand. Agr. Sci.

Senior Research Associate

of Biophotonics Laboratory

e-mail: marinamaslova2009@mail.ru

Federal State Budget

Educational Organization

of Higher Education

«Michurin State

Agrarian University»,

Michurinsk, Russia

To increase the productivity and stability

of fruiting of plants, the horticulture industry needs the adaptive varieties and rootstocks in the specific growing zones. Based on global and local changes in weather and climate conditions, the selection of genotypes resistant to the most often occurring stresses 
к наиболее частым стрессам различного типа, процесс постоянный. В статье показано, что в последние годы особенно актуальными являются направления в селекции по созданию форм подвоев, способных размножаться в условиях повышенных температур весенне-летнего периода и значительного недостатка влаги. Наибольший интерес представляют подвои, которые легко укореняются одревесневшими черенками в первом поле питомника, так как это наименее затратный способ, не требующий больших капитальных вложений. Такие подвои, выделенные уже в питомнике как жаростойкие и засухоустойчивые, значительно увеличивают адаптационный потенциал привойноподвойных комбинаций с их участием. Не менее важной характеристикой на юге России является устойчивость подвоев к бактериальному раку (Agrobacterium tumefaciens). На возбудителя корневого рака положительно действует нейтральная или слабощелочная среда почвы, поэтому на Северном Кавказе часто наблюдается это заболевание, и вредоносность от него значительная, меры борьбы затратны и сложны. В результате проведённых нами исследований выделены подвои, отличающиеся высокой укореняемостью одревесневших черенков в первом поле питомника и устойчивость к корневому раку, - ПК СК 1, ПК СК 2. Они выделены в элиту, запатентованы и введены в Госреестр селекционных достижений. Использование данных подвоев в садоводстве и питомниководстве позволит применять ресурсосберегающие технологии, при этом получать качественный посадочный материал косточковых культур и увеличивать урожайность плодовых насаждений.

Ключевые слова: КЛОНОВЫЕ ПОДВОИ, КОСТОЧКОВЫЕ КУЛЬТУРЫ, УСТОЙЧИВЫЕ ФОРМЫ, УКОРЕНЯЕМОСТЬ, AGROBACTERIUM TUMIFACIENCE, ОДРЕВЕСНЕВШИЕ ЧЕРЕНКИ, ПОГОДНОКЛИМАТИЧЕСКИЕ УСЛОВИЯ The paper shows that in recent years, the directions in breeding to create the rootstocks forms that can reproduce under the conditions of elevated temperatures in the spring-summer period and a significant lack of moisture are especially relevant. The most of interest are rootstocks, which easily rooted by hardwood cuttings in the first field of the nursery, because this is the least costly method does not required large capital investments. Such rootstocks had already identified in the nursery as heat-resistant and drought-resistant, significantly increase in the adaptive potential of scion-rootstock combinations with their participation. An equally important characteristics in the South of Russia is the resistance of rootstocks to the bacterial cancer (Agrobacterium tumefaciens). The pathogen of root cancer is positively affected by a neutral or slightly alkaline soil environment, therefore this disease is often observed in the North Caucasus and its harmfulness is significant, the control disease measures are costly and difficult. As a result of research, we carried out the rootstocks of PK SK 1, PK SK 2 with high rooting of hardwood cuttings in the first field of the nursery and resistance to root cancer were selected. They were allocated to the elite and patented and introduced in the State Register of Selection Achievements. The use of these rootstocks in horticulture and nursery farming will allow us to use the resource-saving technologies and to obtain the high-quality planting material for stone fruit crops and to increase in the yield of fruit orchards.

Key words: CLONAL ROOTSTOCKS, STONE FRUIT CROPS, RESISTANT FORMS, ROOTING, AGROBACTERIUM TUMIFACIENCE, HARDWOOD CUTTINGS, WEATHER AND CLIMATIC CONDITIONS 
Введение. Посадочный материал сортов и подвоев плодовых культур требует постоянного совершенствования сортимента с учётом постепенного изменения климата, состава почв и появления новых болезней плодовых в регионах их возделывания. Получение высоких урожаев в саду и качественного посадочного материала в питомниководческих хозяйствах зависит в большой степени от используемых подвоев, которые должны обладать устойчивостью к абиотическим и биотическим стрессорам среды [1]. Научные исследования, направленные на выявление устойчивости сельскохозяйственных культур к абиотическим стрессорам, являются приоритетными для плодовых культур, которые произрастают на одном месте от 10 до 30 лет и испытывают влияние разнообразных стресс-факторов среды в различные фазы онтогенеза [2, 3].

В последнее время на юге России огромный вред питомникам и молодым садам наносит корневой бактериальный рак - Rhizobium radiobacter, ранее известный как Agrobacterium tumefaciens. Он является наиболее опасным бактериальным патогеном, вызывающим болезнь у более чем 750 различных видов, включая декоративные растения, овощи и фруктовые деревья [4-6]. Появление болезни можно распознать по наростам и галлам на корнях. Наросты образуются на основных, боковых корнях и корневой шейке. Вначале они мелкие, мягкие с гладкой поверхностью, а затем разрастаются, твердеют. Поверхность их из-за образования вторичных наростов становится бугристой. Осенью раковые образования загнивают и разрушаются, выделяя при этом большое количество бактерий, которые попадают в почву и сохраняются там до двух лет даже при отсутствии растения-хозяина [7].

Симптомы болезни становятся очевидными через 2-4 недели после заражения, если температура достигает $20{ }^{\circ} \mathrm{C}$ или выше, обычно совпадая с более высокими температурами почвы в мае или июне. Первоначально галлы выглядят как наросты каллуса, но затем быстро увеличиваются в размерах и количестве. Развитие симптомов значительно замедляется или 
прекращается при температуре почвы ниже $10{ }^{\circ} \mathrm{C}$. При температуре выше 33-35 ${ }^{\circ} \mathrm{C}$ инфекция ингибируется. Симптомы корневого рака обычно развиваются в инфицированной ране в следующем сезоне; в редких случаях галлы не появляются до третьего вегетационного периода [8].

В настоящее время наблюдается расширение ареала заболевания во всех зонах садоводства Краснодарского края: многочисленные очаги выявлены в насаждениях г. Краснодара, Славянского, Крымского, Динского, Тимашевского, Усть-Лабинского районов, в Причерноморской зоне. Часто заболевание заноситься на территорию при покупке некачественного посадочного материала из Европы [9].

Источником инфекции заболевания могут быть корни и корневые остатки, пораженные возбудителем. Освободившиеся после уборки саженцев бактерии переносятся водой, орудиями обработки, на корнях пересаживаемых растений. Они проникают в здоровые корни через механические повреждения, отверстия, прогрызенные майскими жуками, проволочниками и другими вредителями. Затем клетки корней начинают быстро делиться, увеличиваться в объеме, из-за чего и возникают наросты. На возбудителя корневого рака положительно действует нейтральная или слабощелочная среда почвы, кислая реакция почвы их угнетает [7].

Мерами борьбы с корневым раком являются оздоровление почв, заражённых Agrobacterium tumefaciens, и закладка насаждений здоровым, устойчивым к заболеванию посадочным материалом $[10,11]$.

Биологический контроль также успешно используется в лечении заболеваний, однако такие стратегии совершенно неэффективны на загрязненных болезнями почвах или саженцах. Таким образом, производители и ученые в основном сосредоточены на устойчивых к болезням сортах или подвоях [12-15]. Согласно проводимым зарубежным изучениям основных европейских подвоев на предмет чувствительности к бактериальному раку корней было обнаружено, что такие распространённые подвои как GF 677, 
Myrobolan и Marianna, Колт, BВА-1 не обладают устойчивостью к этому заболеванию [16-19].

В Северо-Кавказском федеральном научном центре садоводства, виноградарства, виноделия постоянно проводится мониторинг распространения болезни и оценивается поражаемость растений в коллекционных насаждениях для выделения форм, устойчивых к поражению Agrobacterium tumifacience.

Объекты и методы исследований. Объектами исследований служили подвои для крупнокосточковых культур (сливы, абрикоса и алычи): Дружба, БС-2, Весеннее пламя, Красная лента, АП-1, Эврика 99 (КОССНИИР), ОД-23 (Воронежский ГАУ), GF 655 (Франция), ПК СК 2, ПК СК 1, 534, ПКГ18 1,2 p, 750, 13/935, (СКФНЦСВВ и Ставропольская ОСС). Полевые исследования подвоев в маточном саду и питомнике проведены по стандартным и адаптированным методикам [20,21] в коллекциях и питомниках ООО «ОПХ им. К.А. Тимирязева» (Усть-Лабинский р-н), ЗАО «ОПХ Центральное» СКФНЦСВВ (г. Краснодар).

Обсуждение результатов. В СКФНЦСВВ, начиная с 2003 года, нами изучаются подвои косточковых культур в целях выделения наиболее адаптивных к биотическим и абиотическим факторам среды. Абиотические стрессоры являются одним из основных факторов, влияющих на экономическую эффективность возделывания плодовых культур, особенно в условиях изменяющегося климата [22-24]. Многолетнее изучение погодных условий (за период 1950-2019 гг.) показало, что на юге России важным направлением селекции, особенно в настоящее время, является выявление засухоустойчивых и жаростойких подвоев.

Изменения погодных условий в Краснодарском крае четко прослеживаются даже при анализе среднесуточных данных. Отмечено значительное повышение температуры воздуха в зимний, весенний, летний и осен- 
ний периоды. Тенденция к закономерному увеличению температуры воздуха за анализируемые годы весной и летом показана на трехмерном графике (рис. 1). Особенно выделяется период с 2005 по 2019 год: отмечено увеличение среднесуточной температуры в прикубанской зоне садоводства Краснодарского края на $2,31^{\circ} \mathrm{C}$.

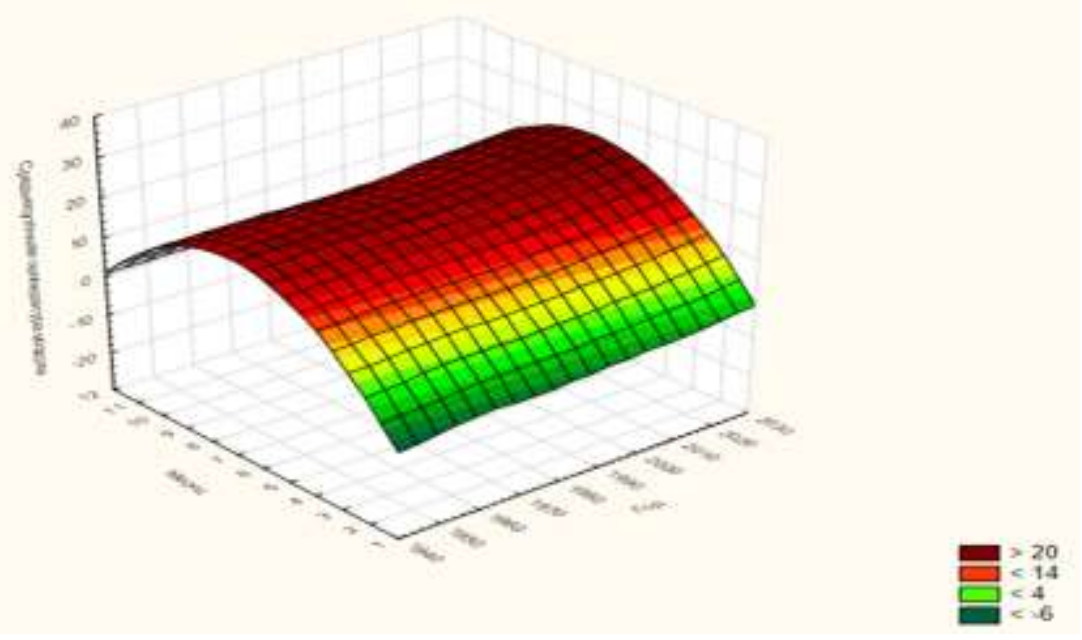

Рис. 1. Повышение среднесуточной температура воздуха за многолетний период 1950-2019 гг. в Прикубанском р-не Краснодарского края на 3D-графике

Начало вегетационного периода в 2019 году, согласно агрометеорологическим данным, также отличалось повышенными среднемесячными температурами, особенно в мае (рис. 2), что негативно отразилось на проценте укореняемости одревесневших черенков значительной части генотипов подвоев, произрастающих в коллекциях СКФНЦСВВ.

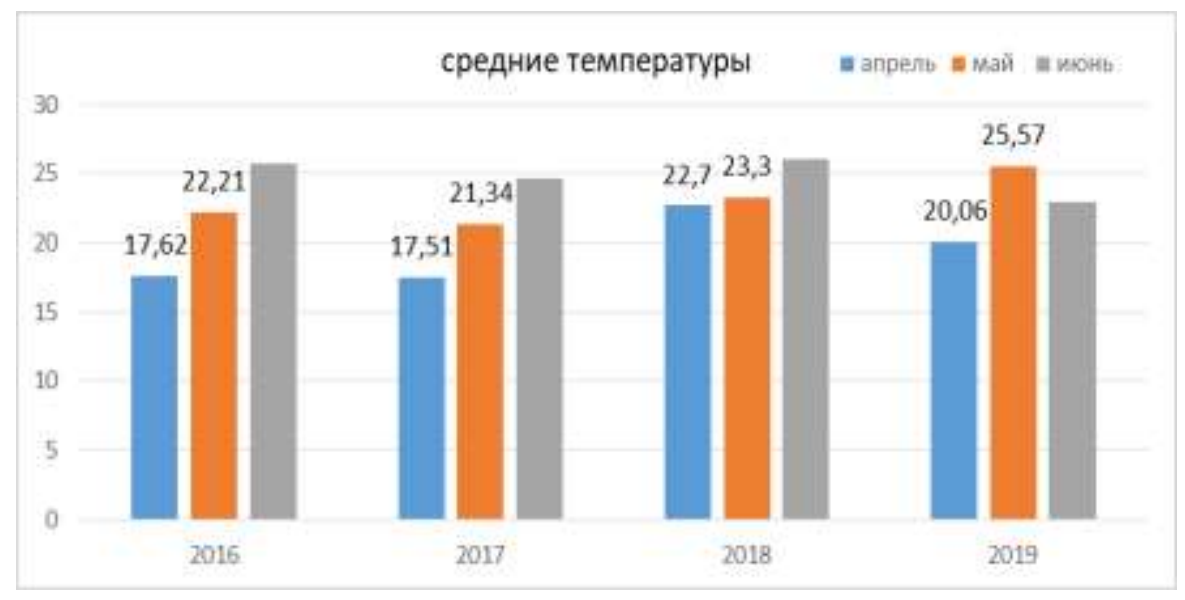

Рис. 2. Сравнение температур в период с апреля по май в прикубанской зоне садоводства Краснодарского края 
Плодоводство и виноградарство Юга России № 64(4), 2020 г.

На этом фоне в 2019 году, в условиях существенного повышения среднесуточных температур, как и в предыдущих испытаниях по укореняемости одревесневших черенков, в первом поле питомника, без орошения, выделились подвои ПК СК 1, ПК СК 2 и новый подвой БС-2. Анализ выделения форм на жёстком фоне без полива показал, что ПК СК 1 и ПК СК 2 показывают высокий процент укореняемости на протяжении длительного периода испытаний, и эта закономерность наблюдалась также при использовании разных препаратов, используемых для повышения ризогенеза растений, что свидетельствует об их высокой общей адаптивности к абиотическим стрессорам, наиболее часто проявляющимся на юге России. (рис. 3,4$)$.

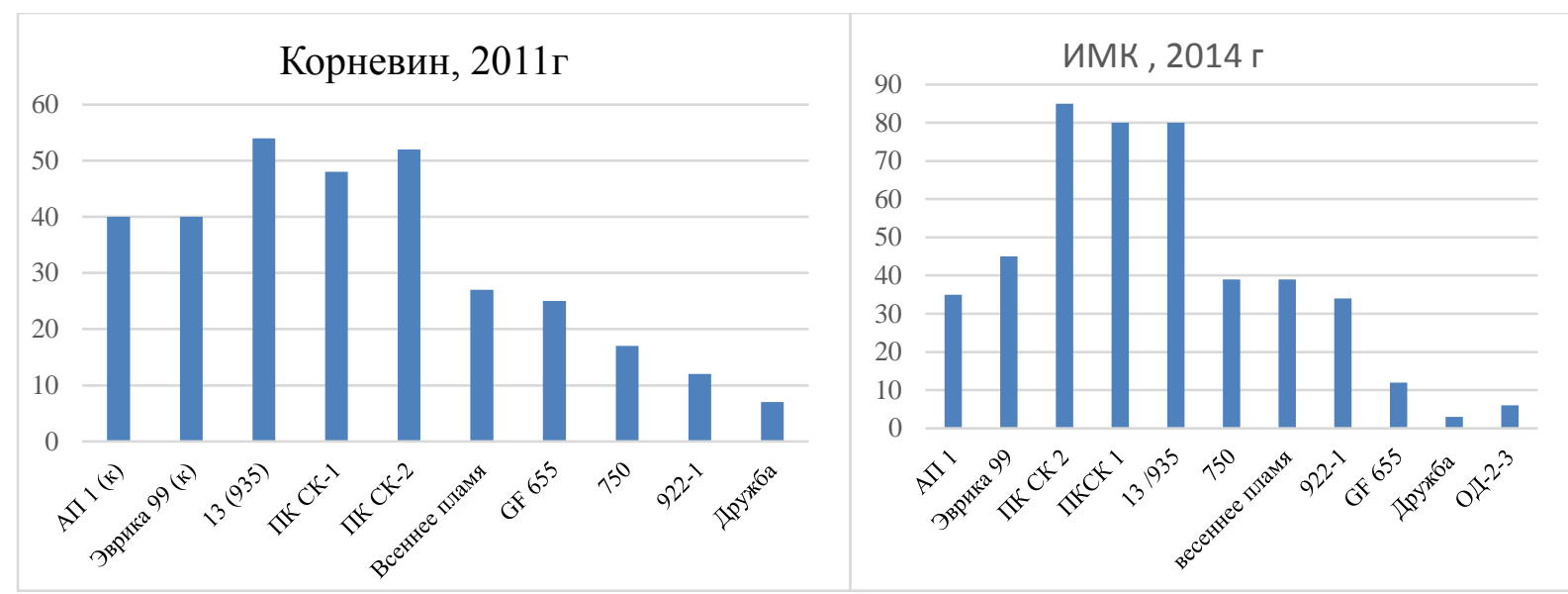

Рис. 3. Укореняемость одревесневших черенков подвоев в первом поле питомника в 2011 и в 2014 гг.

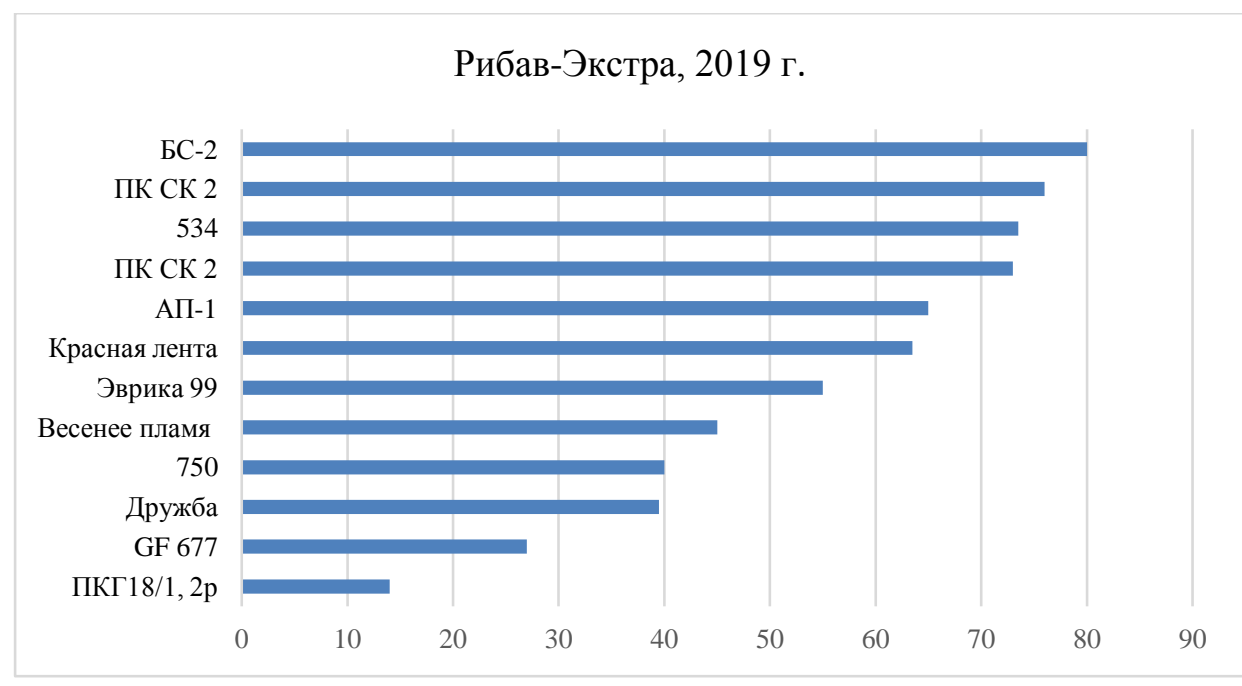

Рис. 4. Укореняемость одревесневших черенков подвоев в первом поле питомника в 2019 году 
Подвои, полученные от растений ПК СК 1 и ПК СК 2, отличались и высоким выходом качественного посадочного материала, в том числе за счёт хорошей совместимости подвоев серии ПК СК с сортами сливы, абрикоса и алычи, приживаемость окулировок в питомнике - до 100 \% (рис. 5).

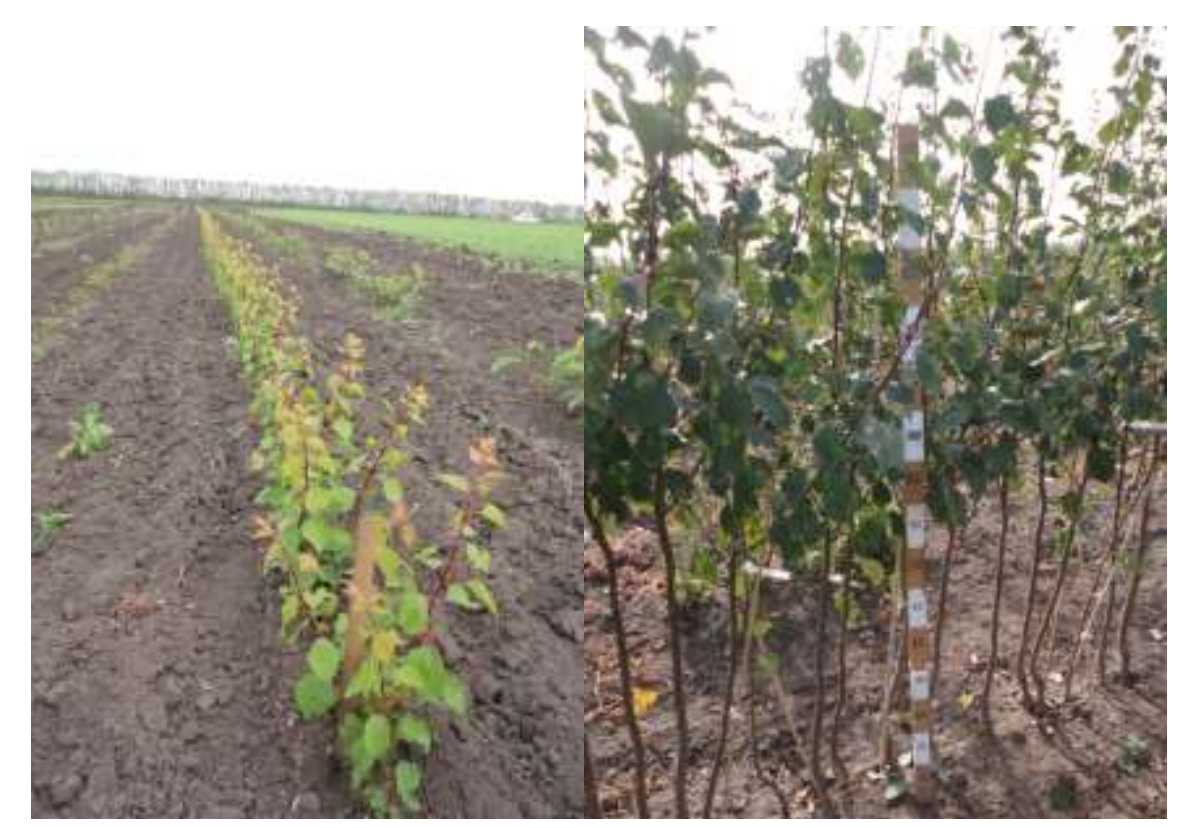

Рис. 5. Приживаемость окулировок жерделы Обильная (слева) и сливы Стенлей (справа) на подвое ПК СК 1

При посадке саженцев сливы на ПК СК 1 в сад (рис. 6) наблюдается разветвлённость надземной части растений, повышение их урожайности, снижение высоты деревьев на $25 \%$ (относительно растений сливы, привитых на семенных подвоях алычи).

В 2018-2019 гг. проведено исследование форм подвоев на предмет устойчивости к корневому раку. Опыт проводился в ящиках с субстратом (в соотношении песок, торф, земля - 1:1:2), в которые были внесены измельчённые корни, заражённые местной популяцией корневого рака, и затем высажены одревесневшие черенки. В опыте использовался препарат для укоренения - Рибав-Экстра. Наибольший процент выхода укоренившихся подвоев в этих условиях был получен при укоренении форм ПК СК 1 и ПК СК 2, что даёт основание считать их толерантными к заболеванию и объясняет высокий процент выхода посадочного материала на этих подвоях в различных зонах произрастания (рис. 7) [25, 26]. 


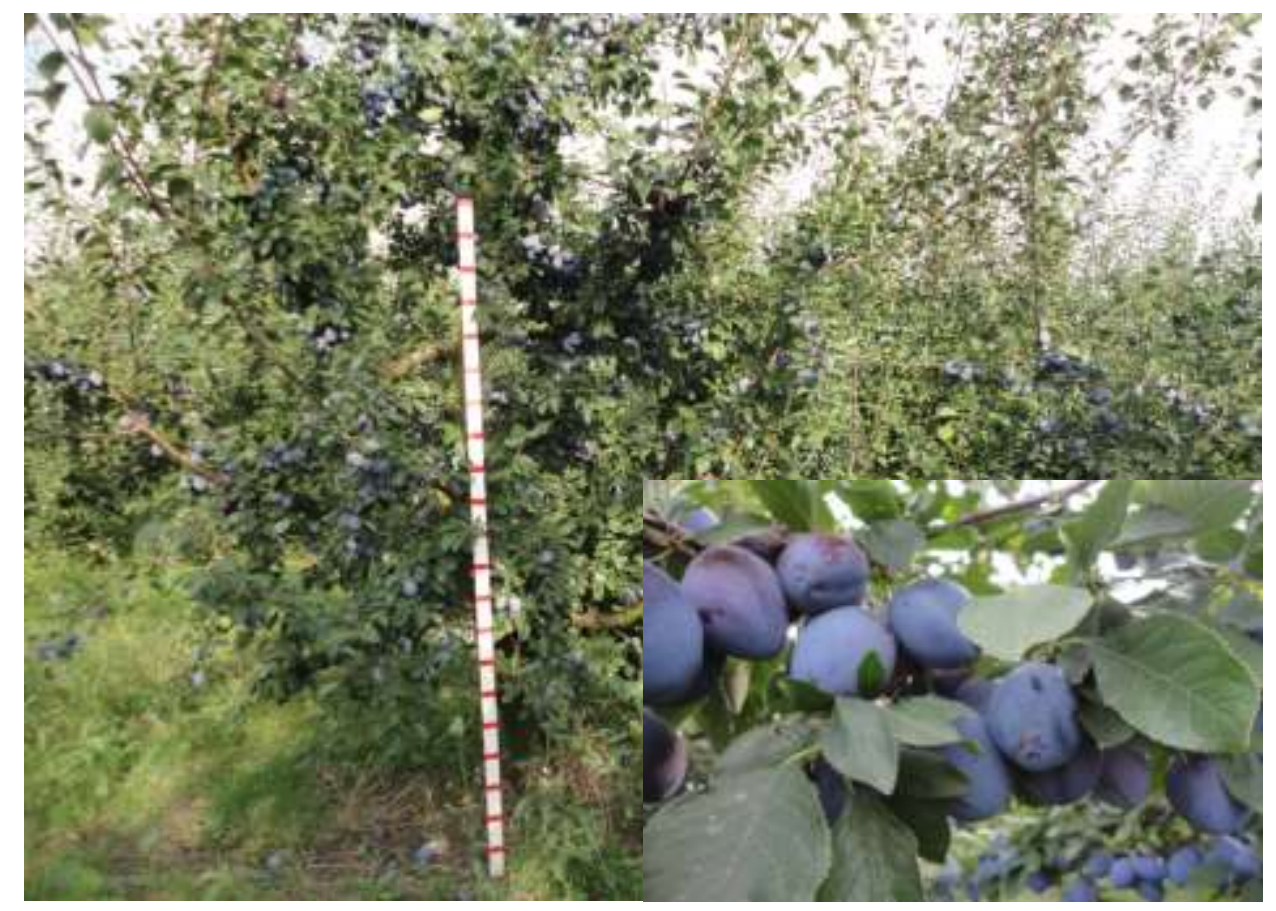

Рис. 6. Урожайность сливы Стенлей на подвое ПК СК 1 в саду ООО «Плодовод», 2019 г.

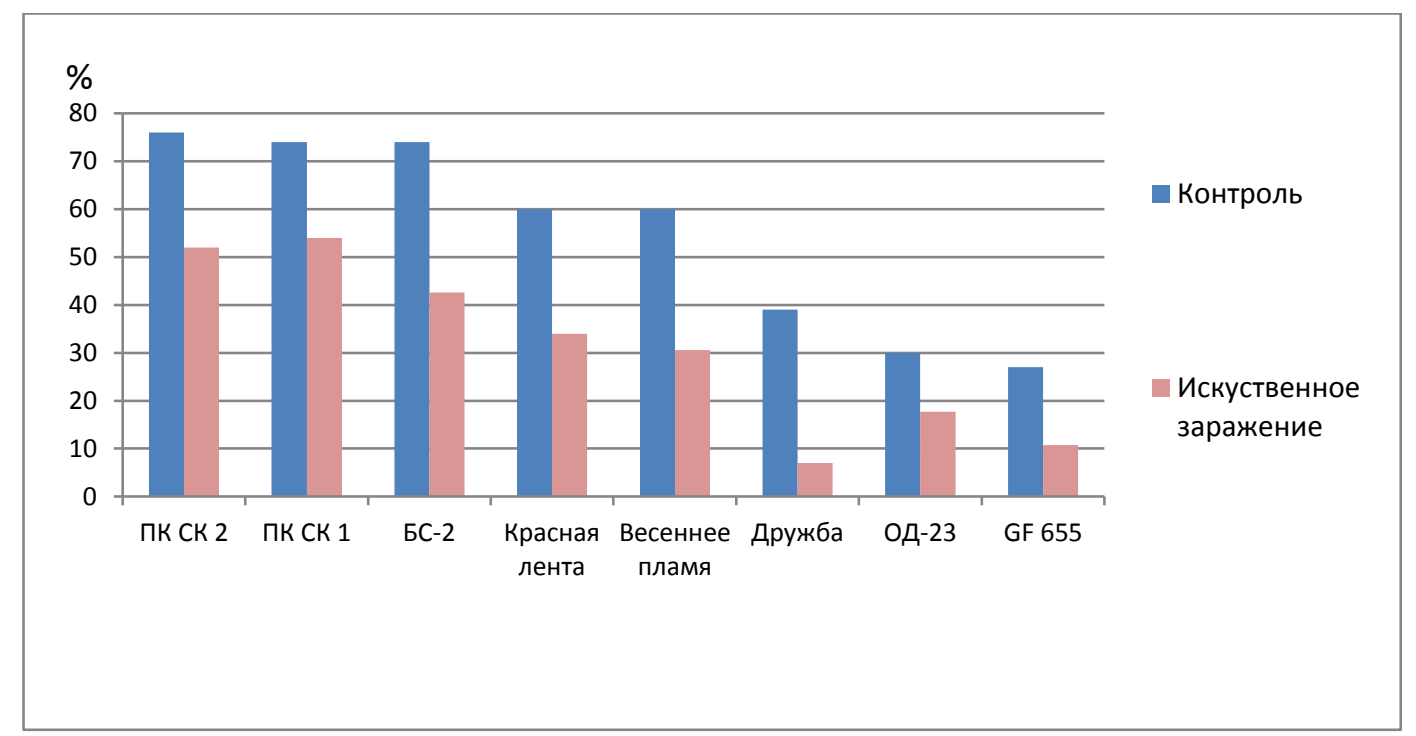

Рис. 7. Процент выхода подвоев при заражении корней популяцией Agrobacterium tumefacien (внесение в субстрат для укоренения), 2018-2019 гг.

Подвой ПК СК 1 (Prunus pumila L. x Prunus cerasifera Ehrh.) х (P. cerasifera Ehrh.). Включён в Госреестр селекционных достижений, допущенных к размножению в РФ. 
Деревья крупнокосточковых культур на этом подвое среднерослые (на 25 \% ниже алычи), отличаются хорошей урожайностью. Якорность деревьев хорошая, корневой поросли не образует, устойчив к плотным тяжелым, переувлажненным почвам. Засухоустойчив и морозостоек. Имеет высокую укореняемость одревесневших черенков в первом поле питомника, приживаемость глазков при окулировке 95-98 \%. Выход подвоев из одревесневших черенков 60-70 \%. Клястероспориозом поражается в очень слабой степени, устойчив к полистигмозу и корневому раку. Деревья на этом подвое рано вступают в плодоношение (рис. 8).

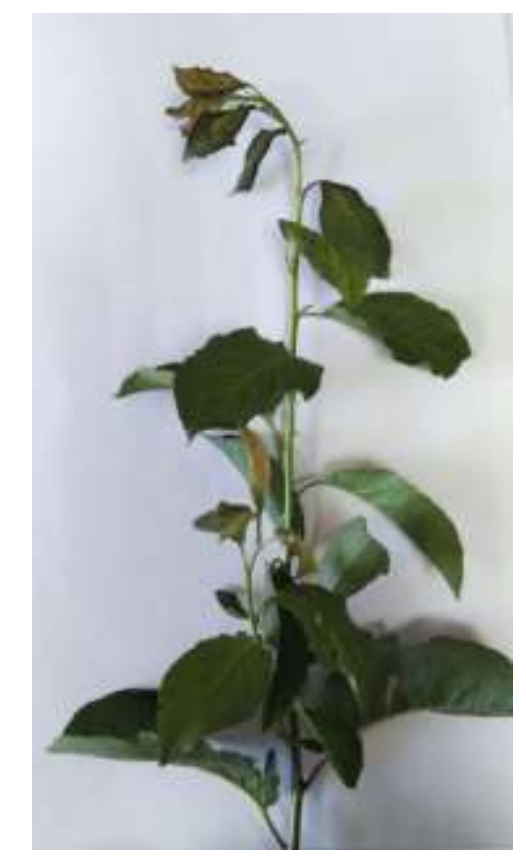

Рис. 8. Подвой ПК СК 1

Достоинства: высокая адаптивность в условиях Северного Кавказа, высокие основные показатели подвоев в питомнике (процент укоренения одревесневшими черенками, зимостойкость, засухоустойчивость). Формирует мощную, густую корневую систему, способствующую хорошей якорности привитых деревьев в саду. Недостаток - в первом поле питомника часто проявляется излишнее образование боковых побегов.

Рекомендуется для использования в интенсивных садах сливы, алычи, абрикоса с плотностью размещения до 1000 деревьев на гектар. 
Подвой ПК СК 2 (Prunus munsoniana Wight) х (P. cerasifera Ehrh.). Включен в Госреестр селекционных достижений, допущенных к размножению в РФ.

Деревья крупнокосточковых культур на этом подвое среднерослые (на 25\% ниже алычи), отличаются высокой урожайностью. Отмечена хорошая якорность деревьев даже в условиях выращивания на плотных тяжелых, переувлажненных почвах. Отличается устойчивостью к морозам в бесснежные зимы. Показывает высокую укореняемость одревесневших черенков в питомнике, даже при недостатке влаги и высоких температурах весенне-летнего периода. Привойно-подвойные комбинации сливы на нем рекомендуются для закладки ресурсосберегающих садов. Имеет приживаемость глазков при окулировке 95-98 \%. Укореняемость одревесневших черенков высокая - 70-80 \%. Клястероспориозом поражается в очень слабой степени, устойчив к полистигмозу и корневому раку. Деревья на этом подвое отличаются ранним вступлением в плодоношение (рис. 9).

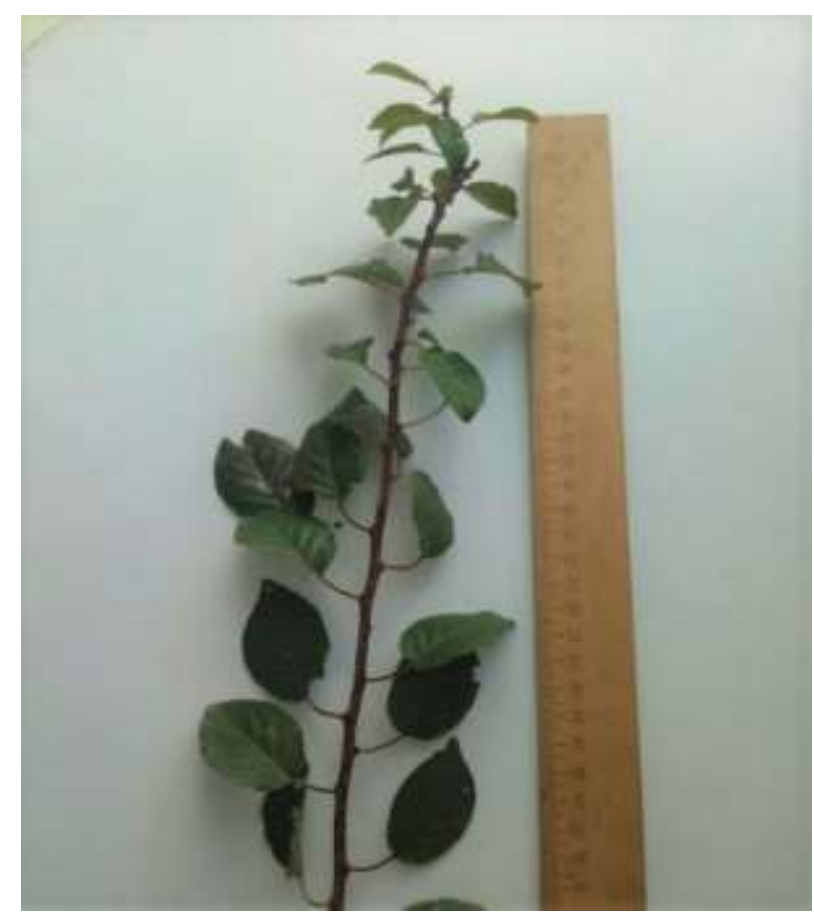

Рис. 9. Подвой ПК СК 2 
Плодоводство и виноградарство Юга России № 64(4), 2020 г.

Достоинства: высокий процент укоренения одревесневших черенков, зимостойкость, засухоустойчивость, отличная якорность деревьев. Недостаток - в первом поле питомника на чернозёмах наблюдается перерастание подвоев, для устранения необходимо использовать более плотные схемы посадки. Рекомендуется для использования в интенсивных садах сливы с плотностью размещения до 1000 деревьев на гектар.

Bыводы. В результате селекции на создание адаптивных подвоев запатентованы и введены Госреестр селекционных достижений подвои для крупнокосточковых культур ПК СК 1, ПК СК 2, отличающиеся высокой укореняемостью одревесневших черенков в условиях недостатка влаги, устойчивостью к корневому бактериальному раку и превосходящие районированные среднерослые подвои по комплексу других хозяйственно ценных признаков в условиях юга России.

Использование данных подвоев, устойчивых к абиотическим и биотическим стресс-факторам среды, в садоводстве и питомниководстве позволяет получать качественный посадочный материал косточковых культур даже в условиях недостатка влаги, увеличивать урожайность плодовых насаждений и минимизировать пестицидную нагрузку в питомнике.

\section{Литература}

1. Beckman T.G., Lang G.A. Rootstock breeding for stone fruits // Acta Horticulturae. 2003. Vol. 622. P. 531-51.

2. Егоров Е.А., Шадрина Ж.А., Кочьян Г.А. Перспективные сортименты и технологии в садоводстве - технолого-экономический аспект // Научные труды СКФНЦСВВ. Т. 17. Краснодар, СКФНЦСВВ, 2018.С. 7-19.

3. Драгавцева И.А., Ахматова 3.П., Моренец А.С. Особенности и тенденции вариабельности лимитирующих факторов среды для плодовых культур Северного Кавказа в зимне-весенний период с четом изменения климата (на примере абрикоса) // Садоводство и виноградарство. 2018. № 4. С. 38-43.

4. Horuz S., Cağlar B.K., Küsek M., Aysan Y. Crown gall disease susceptibility of some stone fruit rootstocks in turkey // Journal of agricultural sciences. 2017. V. 24. P. 2148-9297.

5. Pulawska J. Crown gall of stone fruits and nuts, economic significance and diversity of its causal agents: tumorigenic agrobacterium spp. // Journal of Plant Pathology. 2010. Vol. 92. P. 87-98. 
6. Bouzar H., Daouzli N., Krimi Z., Alim A., Khemici E. Crown gall incidence in plant nurseries of Algeria,characteristics of Agrobacterium tumefaciens strains, and biological control of strains sensitive andresistant to agrocin 84 // Agronomie, EDP Sciences. 1991. 11 (10). P.901-908.

7. Копиця В.Н. Раковые болезни плодовых деревьев: особенности их развития и разработка защитных мероприятий. Минск: Белнаучцентринформаркетинг АПК, 2000. $35 \mathrm{c}$.

8. Moore L.W., Putnam M.L. Crown Gall Disease of Nursery Crops https://pnwhandbooks.org/plantdisease/pathogen-articles/pathogens-common-many-plants/ bacteria-other-prokaryotes/crown-gall Дата обращения: 19.03.2020

9. Кузнецова А.П., Тыщенко Е.Л. Приоритетные направления развития современного питомниководства в связи с решением проблем импортозамещения // Плодоводство и виноградарство Юга России [Электронный ресурс]. 2016. № 41 (5). С. 74-86. URL: http://journal.kubansad.ru/pdf/16/05/08.pdf.

10. Kerr A. Biological control of Crown Gall // Australasian Plant Patholgy. 2016. Vol. 45. P. 15-18.

11. Бунцевич Л.Л., Винтер М.А., Щербаков Н.А. Оздоровление питомников сливы и других косточковых культур от бактериального рака корней, современные методические подходы // Плодоводство виноградарство Юга России [Электронный ресурс]. 2018. № 50 (2). С. 56-66. URL: https://www.elibrary.ru/item.asp?id=32601806

12. Магер М.К. Бактериальный корневой рак плодовых культур в Молдавии и меры борьбы с ним // Защита плодовых культур от вредителей и болезней. 1986. C. $139-156$.

13. Кузнецова А.П., Тыщенко Е.Л. Тенденции развития отечественного питомниководства на современном этапе // Труды Кубанского государственного аграрного университета. 2015. № 55. С. 124-128.

14. Gainza F., Opazo I., Guajardo V., Meza P., Ortiz M., Pinochet J., Muñoz C. Rootstock breeding in Prunus species: Ongoing efforts and new challenges // Chilean journal of agricultural research. 2015. Vol. 75. P. 6-16.

15. Rhouma, A., Boubaker, A., Nesme, X., \& Dessaux, Y. Susceptibility of some stone and pome fruit rootstocks to crown gall // Phytopathologia Mediterrane. 2005. 44(3). P. 275-284.

16. Guzman G., Latorre B.A., Torres R., Wilcox W.F. Relative susceptibility of peach rootstocks to crown gall and Phytophthora root and crown rot in Chile // Ciencia e investigación agraria. 2007. Vol. 34. P. 31-40.

17. Stassen P. Rootstocks for plums // Hortgro science [El. Journal] https://www.hortgro-science.co.za/wp-content/uploads/docs/2018/08/Rootstocks-for-plums.pdf

18. Thomidis T., Exadaktylou E., Tsipouridis C. Susceptibility of five Prunus rootstocks to Agrobacterium tumefaciens // New Zealand Journal of Crop and Horticultural Science. 2005. Vol. 33:4. P. 343-345.

19. Атлас лучших сортов плодовых и ягодных культур Краснодарского края. Т. 3. Краснодар: ГНУ СКЗНИИСиВ, 2011. 203 с.

20. Методика опытного дела и методические рекомендации Северо-Кавказского зонального НИИ садоводства и виноградарства. Краснодар, 2002. 215 с.

21. Программа и методика сортоизучения плодовых, ягодных и орехоплодных культур; под общ. ред. Е.Н. Седова и Т.П. Огольцовой. Орел: ВНИИ селекции плодовых культур, 1999. 608 с.

22. Супрун И.И. Новые генетические методы и способы повышения стрессоустойчивости плодовых культур и винограда // Методы и способы повышения стрессоустойчивости плодовых культур и винограда: сборник материалов межд. дистанц. науч.-практ. конф.. Краснодар: СКЗНИИСиВ, 2009. С. 3-9. 
23. Ненько Н.И., Макарова Э.В., Кузнецова А.П., Якуба Ю.Ф. Физиологобиохимические аспекты повышения стрессоустойчивости плодовых культур и винограда // Методы и способы повышения стрессоустойчивости плодовых культур и винограда: сборник материалов межд. дистанц. науч.-практ. конф. Краснодар: СКЗНИИСиВ, 2009. С. $42-54$.

24. Груза Г.В., Ранькова Э.Я. Обнаружение изменений климата: состояние, изменчивость и экстремальность климата // Метеорология и гидрология. 2004. № 4. С. 50-65.

25. Основные направления и итоги совместных исследований СКФНЦСВВ и СОСС по селекции плодовых растений / Е.В. Ульяновская [и др.] // Научные труды СКФНЦСВВ Т. 22. Краснодар: СКФНЦСВВ, 2019. С. 18-30.

26. Кузнецова А.П., Воронов А.А. Оценка устойчивости подвоев косточковых культур к абиотическим факторам среды в условиях Краснодарского края // Садоводство и виноградарство. 2008. № 6. С. 17-18.

\section{References}

1. Beckman T.G., Lang G.A. Rootstock breeding for stone fruits // Acta Horticulturae. 2003. Vol. 622. P. 531-51.

2. Egorov E.A., Shadrina Zh.A., Koch'yan G.A. Perspektivnye sortimenty i tekhnologii v sadovodstve - tekhnologo-ekonomicheskij aspekt // Nauchnye trudy SeveroKavkazskogo federal'nogo nauchnogo centra sadovodstva, vinogradarstva, vinodeliya. T. 17. Krasnodar, SKFNCSVV, 2018.S. 7-19.

3. Dragavceva I.A., Ahmatova Z.P., Morenec A.S. Osobennosti i tendencii variabel'nosti limitiruyushchih faktorov sredy dlya plodovyh kul'tur Severnogo Kavkaza v zimnevesennij period s chetom iz-meneniya klimata (na primere abrikosa) // Sadovodstvo i vinogradarstvo. 2018. № 4. S. 38-43.

4. Horuz S., Cağlar B.K., Küsek M., Aysan Y. Crown gall disease susceptibility of some stone fruit rootstocks in turkey // Journal of agricultural sciences. 2017. V. 24. P. 2148-9297.

5. Pulawska J. Crown gall of stone fruits and nuts, economic significance and diversity of its causal agents: tumorigenic agrobacterium spp. // Journal of Plant Pathology. 2010. Vol. 92. P. 87-98.

6. Bouzar H., Daouzli N., Krimi Z., Alim A., Khemici E. Crown gall incidence in plant nurseries of Algeria,characteristics of Agrobacterium tumefaciens strains, and biological control of strains sensitive andresistant to agrocin 84 // Agronomie, EDP Sciences. 1991. 11 (10). P.901-908.

7. Kopicya V.N. Rakovye bolezni plodovyh derev'ev: osobennosti ih razvitiya i razrabotka zashchitnyh meropriyatij. Minsk: Belnauchcentrinformarketing APK, 2000. 35 s.

8. Moore L.W., Putnam M.L. Crown Gall Disease of Nursery Crops https://pnwhandbooks.org/plantdisease/pathogen-articles/pathogens-common-many-plants/ bacteria-other-prokaryotes/crown-gall Data obrashcheniya: 19.03.2020

9. Kuznecova A.P., Tyshchenko E.L. Prioritetnye napravleniya razvitiya sovremennogo pitomnikovodstva $\mathrm{v}$ svyazi s resheniem problem importozameshcheniya // Plodovodstvo i vinogradarstvo Yuga Rossii [Elektronnyj resurs]. 2016. № 41 (5). S. 74-86. URL: http://journal.kubansad.ru/pdf/16/05/08.pdf.

10. Kerr A. Biological control of Crown Gall // Australasian Plant Patholgy. 2016. Vol. 45. P. 15-18.

11. Buncevich L.L., Vinter M.A., Shcherbakov N.A. Ozdorovlenie pitomnikov slivy i drugih kostochkovyh kul'tur ot bakterial'nogo raka kornej, sovremennye metodicheskie podhody // Plodovodstvo vinogradarstvo Yuga Rossii [Elektronnyj resurs]. 2018. № 50 (2). S. 56-66. URL: https://www.elibrary.ru/item.asp?id=32601806 
12. Mager M.K. Bakterial'nyj kornevoj rak plodovyh kul'tur v Moldavii i mery bor'by s nim // Zashchita plodovyh kul'tur ot vreditelej i boleznej. 1986. S. 139-156.

13. Kuznecova A.P., Tyshchenko E.L. Tendencii razvitiya otechestvennogo pitomnikovodstva na sovremennom etape // Trudy Kubanskogo gosudarstvennogo agrarnogo universiteta. 2015. № 55. S. 124-128.

14. Gainza F., Opazo I., Guajardo V., Meza P., Ortiz M., Pinochet J., Muñoz C. Rootstock breeding in Prunus species: Ongoing efforts and new challenges // Chilean journal of agricultural research. 2015. Vol. 75. P. 6-16.

15. Rhouma, A., Boubaker, A., Nesme, X., \& Dessaux, Y. Susceptibility of some stone and pome fruit rootstocks to crown gall // Phytopatho-logia Mediterrane. 2005. 44(3). R.275-284.

16. Guzman G., Latorre B.A., Torres R., Wilcox W.F. Relative susceptibility of peach rootstocks to crown gall and Phytophthora root and crown rot in Chile // Ciencia e investigación agraria. 2007. Vol. 34. P. 31-40.

17. Stassen P. Rootstocks for plums // Hortgro science [El. Journal] https://www.hortgro-science.co.za/wp-content/uploads/docs/2018/08/Rootstocks-forplums.pdf

18. Thomidis T., Exadaktylou E., Tsipouridis C. Susceptibility of five Prunus rootstocks to Agrobacterium tumefaciens // New Zealand Journal of Crop and Horticultural Science. 2005. Vol. 33:4. P. 343-345.

19. Atlas luchshih sortov plodovyh i yagodnyh kul'tur Krasnodarskogo kraya. T. 3. Krasnodar: GNU SKZNIISiV, 2011. 203 s.

20. Metodika opytnogo dela i metodicheskie rekomendacii Severo-Kavkazskogo zonal'nogo NII sadovodstva i vinogradarstva. Krasnodar, 2002. $215 \mathrm{~s}$.

21. Programma i metodika sortoizucheniya plodovyh, yagodnyh i orekhoplodnyh kul'tur; pod obshch. red. E.N. Sedova i T.P. Ogol'covoj. Orel: VNII selekcii plodovyh kul'tur, 1999. $608 \mathrm{~s}$.

22. Suprun I.I. Novye geneticheskie metody i sposoby povysheniya stressoustojchivosti plodovyh kul'tur i vinograda // Metody i sposoby povysheniya stressoustojchivosti plodovyh kul'tur i vinograda: sbornik materialov mezhd. distanc. nauch.prakt. konf.. Krasnodar: SKZNIISiV, 2009. S. 3-9.

23. Nen'ko N.I., Makarova E.V., Kuznecova A.P., Yakuba Yu.F. Fiziologobiohimicheskie aspekty povysheniya stressoustojchivosti plodovyh kul'tur i vinograda // Metody i sposoby povysheniya stressoustojchivosti plodovyh kul'tur i vinograda: sbornik materialov mezhd. distanc. nauch.-prakt. konf. Krasnodar: SKZNIISiV, 2009. S. 42-54.

24. Gruza G.V., Ran'kova E.Ya. Obnaruzhenie izmenenij klimata: sostoyanie, izmenchivost' i ekstremal'nost' klimata // Meteorologiya i gidrologiya. 2004. № 4. S. 50-65.

25. Osnovnye napravleniya i itogi sovmestnyh issledovanij SKFNCSVV i SOSS po selekcii plodovyh rastenij / E.V. Ul'yanovskaya [i dr.] // Nauchnye trudy SeveroKavkazskogo federal'nogo nauchnogo centra sadovodstva, vinogradarstva, vinodeliya. T. 22. Krasnodar: SKFNCSVV, 2019. S. 18-30.

26. Kuznecova A.P., Voronov A.A. Ocenka ustojchivosti podvoev kostochkovyh kul'tur k abioticheskim faktoram sredy v usloviyah Krasnodarskogo kraya // Sadovodstvo i vinogradarstvo. 2008. № 6. S. 17-18. 